of investigating the behaviour of semiconductor materials. The student will also gain a sound background in nuclear and atomic physics and solid state theory. The object of the course is to produce nuclear and solid state technologists able to apply themselves to problems which do not fall into the individual category of nuclear physics, solid state physics or electrical materials.

\section{Money for Caltech}

A campaign to raise $\$ 85 \cdot 4$ million in capital funds has been launched by the California Institute of Technology. This includes $\$ 20$ million for the endowment of faculty salaries, $\$ 30$ million for new buildings and renovations and $\$ 35$ million for the increased operating costs of its academic programmes and physical plant. The president, Dr L. A. Dubridge, suggests that the most urgently required buildings are a geophysics and planetary sciences laboratory ( $\$ 2.45$ million), a cyclotron building to house a particle accelerator $(\$ 1.7$ million), an applied mathematics building $(\$ 1.625$ million) and an engineering laboratory to provide room for an increasing variety of projects in the fields of electronics, materials, aeronautics and hydraulics. Four halls of residence are also required for unmarried students ( $\$ 2.425$ million) and a new physical education building is also needed ( $\$ 1 \cdot 15$ million). Last but not least, a building is needed to house the Buildings Operations department, already the largest business activity in the city of Pasadena ( $\$ 2.425$ million).

Caltech already owns the land necessary for the new buildings, according to Dr Dubridge, and some of the buildings will be located on the main campus.

\section{Scant Recognition}

The discovery of radium by Pierre and Marie Curie is being marked by an exhibit in the Atomic Physics Gallery of the Science Museum, London. Visitors should go up to the second floor and proceed to section 44 where, if they look carefully, they will see an unobtrusive picture of Marie Curie bearing the following inscription: "Becquerel discovered the radioactivity of uranium in 1896 and in 1898 Madame Curie showed that thorium was also radioactive. In the same year, Pierre and Madame Curie, working together, succeeded in separating from uranium ores two much more strongly radioactive elements which they named polonium and radium. In her later life, Madame Curie played a greater part in the application of radium and other radioactive substances in medicine."

It is to be hoped that the museum will do better when, next month, it celebrates the 25 th anniversary of the first controlled nuclear pile, built by Enrico Fermi at Chicago.

\section{'Nature' Appointment}

Dr JohN Tooze, a lecturer in the Department of Biophysics at King's College, London, will join the staff of Nature as Assistant Editor early in the New Year. Dr Tooze was educated at Jesus College, Cambridge, and has spent some time at the biology laboratories at Harvard University on a Wellcome Trust postdoctoral fellowship. In the next few months he will be helping with the production of the journal.

\section{Parliament in Britain}

\section{Education}

THE Government should keep an open mind on the question of loans and grants for postgraduate education. according to Sir Edward Boyle, Opposition spokesman on education. He was speaking in a debate on the Queen's Address, in which Conservative members took the opportunity of criticizing Mr Patrick Gordon Walker's handling of comprehensive schooling and the British Museum. Nothing should be done to deter working class children from going to university, he said, but if we wanted a large expansion in post. graduate education in the seventies, the possibility of a loan element should not be forgotten. Sir Edward also said that the Government's new target figure of 220,000 to 225,000 students by 1971 was too low, although it was well above the Robbins predictions. The vice-chancellors' committee, he said, had put the figure at 245,000. Why had the Government not accepted this ?

Mr Gordon Walker first explained his position on the British Museum. He had been charged, he said, with reversing a firm decision to go ahead with the Bloomsbury scheme. This was simply not true. "There was no clear decision by the previous government, nor any firmness of action or clarity of purpose. On the contrary, it was a sorry tale of indecision." Several members were reluctant to accept this version of events, but Mrs Lena Jeger leapt to the defence of Mr Gordon Walker. It was, she said, an unbearable hypocrisy for Conservative members to appear as the sudden friends of the British Museum and sudden lovers of books. The recent report of the British Museum Trustees was an indictment of successive governments. It was certainly no comfort to any of them.

Finally, Mrs Shirley Williams was able to answer Sir Edward's question. The vice-chancellors' estimate of 245,000 students by 1971 was simply the adding together of the reasonable ambitions of all vicechancellors, and was not put forward as a collective view. The target of 225,000 would be met without damaging other parts of higher education by trying to shift resources even further towards university expansion. (Debate, November 3.)

\section{Child Care}

LoRd Stonham, Minister of State, Home Office said that the Home Secretary had decided to establish a development group within the Children's Department and Inspectorate. The group would work in close co-operation with the universities, the professional associations and organizations such as the National Bureau for Co-operation in Child Care, seeking to supplement and support the research and development work which these bodies already undertook. The Home Secretary had also proposed to the local authority associations that the present Advisory Council on Child Care and the Central Training Council should be reconstituted and amalgamated to become the central forum for the co-operative discussions and steering of research, development and training in child care. The reconstituted council would be supported in its work by the new development group and by the Home Office Research Unit, both of which would undertake projects within programmes drawn up by the council and approved by the Home Secretary and the local authority associations. (Debate, October 25.) 